Stefania Lima Oliveira ${ }^{1+}$, Ticyane Pereira Freire', Tamires Galvão Tavares Pereira', Lourival Marin Mendes', Rafael Farinassi Mendes'

\title{
LAMINAR INCLUSION IN SUGARCANE BAGASSE PARTICLEBOARD
}

Keywords:

Lignocellulosic waste

Com-ply

Physical and mechanical properties

Histórico:

Recebido 13/09/2016

Aceito 24/03/2017

Palavras chave: Resíduo lignocelulósico

Com-ply

Propriedades físicas e mecânicas

${ }^{+}$Correspondência: stefaniaoliveira@yahoo.com.br
ABSTRACT: The objective of this study is to assess the effect of the laminar inclusion on the physical and mechanical properties of sugarcane bagasse particleboard. We used the commercial panels of sugarcane bagasse produced in China. To evaluate the effect of the laminar inclusion was tested two wood species (Pinus and Eucalyptus) and two pressures ( 10 and $15 \mathrm{~kg} \cdot \mathrm{cm}^{-2}$ ) along with a control (without laminar inclusion). The panels with laminar inclusion obtained improvements in the physical properties, with a significant reduction in the WA2h, WA24h and TS2h. There was a significant increase in the properties MOE and MOR parallel and Janka hardness, while the properties MOE and MOR perpendicular decreased significantly. The pinus and eucalyptus veneers inclusion resulted in similar results when added to the panel with a $10 \mathrm{~kg} \cdot \mathrm{cm}^{-2}$ pressure. The use of $15 \mathrm{kgf} \cdot \mathrm{cm}^{-2}$ pressure is not indicated for the pinus veneer inclusion in sugar cane bagasse panels. There was no effect of the pressure level when evaluating the eucalyptus veneer inclusion on the properties of the sugarcane bagasse panels.

\section{INCLUSÃO LAMINAR EM PAINÉIS AGLOMERADOS DE BAGAÇO DE CANA DE AÇÚCAR}

RESUMO: O objetivo deste estudo é avaliar o efeito da inclusão laminar sobre as propriedades físicas e mecânicas de painéis aglomerados de bagaço de cana-de-açúcar. Foram utilizados painéis comerciais de bagaço de cana-de-açúcar produzidos na China. Para avaliar o efeito da inclusão laminar foram avaliadas duas espécies de madeira (Pinus e Eucalyptus) e duas pressões ( 10 e I5 $\mathrm{kgf} \cdot \mathrm{cm}^{-2}$ ), juntamente com um controle (sem inclusão laminar). Os painéis com inclusão laminar obtiveram melhorias nas propriedades físicas, com uma redução significativa na AA2h, AA24h e IE2h. Houve um aumento significativo nas propriedades MOE e MOR paralelo e dureza janka, enquanto as propriedades MOE e MOR perpendicular diminuíram significativamente. A inclusão laminar de pinus e eucalipto resultou em resultados semelhantes quando adicionadas ao painel com uma pressão de 10 $\mathrm{kgf} \cdot \mathrm{cm}^{-2}$. O uso de pressão de $15 \mathrm{kgf} \cdot \mathrm{cm}^{-2}$ não é indicado para a inclusão laminar de pinus em painéis de bagaço de cana-de-açúcar. Não houve efeito do nível de pressão ao avaliar a inclusão laminar de eucalipto nas propriedades dos painéis de bagaço de cana-de-açúcar. 


\section{INTRODUCTION}

The furniture sector in Brazil has shown tremendous growth and development over the recent years, leading to a significant increase in the production of particleboard, given their wide use in furniture manufacture (OLIVEIRA, 2016).

In panel manufacture, currently wood from planted forests is primarily used, particularly those of the genus Pinus and Eucalyptus. However, in principle, these panels can be produced by utilizing any lignocellulosic material, which can confer high mechanical strength and exhibit good physical characteristics (ROWELL et al., 2000; MENDES et al., 2012).

In light of this knowledge, the utilization of the waste generated by the agribusiness is considered a good alternative to meet the demand of the panel industry. Among the agricultural wastes available, bagasse shows the greatest promise. World sugarcane production in the 2015/2016 was equivalent to 164.9 million tons (USDA, 2016). Which results in approximately 46 million tons of sugarcane bagasse, because according to Silva et al. (2007), each ton of processed sugarcane produces a total of $280 \mathrm{~kg}$ of waste.

Some researchs which had been conducted using sugarcane bagasse in the production of particleboard highlighted its great potential in this field (WIDYORINI et al., 2005; MENDES et al., 2009; XU et al., 2009; BARROS SON et al., 20II; MENDES et al., 20l2b). However, in panel production due to its lower density it requires a greater number of bagasse particles, which increases their compressive stresses at the time of pressing, as well as a higher number of hygroscopic sites, thereby making the panel more susceptible to water absorption and dimensional variation than the ones produced by using Pinus and Eucalyptus woods (MENDES et al., 2008).

Other researches aimed at improving the dimensional stability and mechanical strength of wood particleboard continue to be developed (KNOW et al. 20I3; VITAL et al. 20I4; ANDRADE et al. 20I6). Among which we can mention the inclusion or laminar-ply, characterized by the insertion of veneers on the panel faces. This enables the enhancement of the physical and mechanical properties, as well as the aesthetics and finish of the product (IWAKIRI, 2003). However, the laminar inclusion has not yet been evaluated for sugarcane bagasse panels.

Thus, the objective of this study was to evaluate the effect of the laminar inclusion on the physical and mechanical properties of the sugarcane bagasse particleboard.

\section{MATERIAL AND METHODS}

\section{Material}

The commercial sugarcane bagasse particleboard produced in China were used. These panels were divided into $50 \times 50 \mathrm{~cm}$ in dimension, and air-conditioned in a room at a temperature of $22 \pm 2{ }^{\circ} \mathrm{C}$ and relative humidity of $65 \pm 5 \%$.

The Eucalyptus grandis logs, with 26 years old, and Pinus oocarpa logs, with 22 years old, were obtained at an experimental planting on the campus of the Federal University of Lavras, Lavras - MG.

Production and classification of veneers

Previously to veneeering, the logs were peeled and water heated at $65^{\circ} \mathrm{C}$ for 24 hours. They were veneered to obtain $2.00 \mathrm{~mm}$ thick veneers.

These veneers were then guillotined with dimensions of $0.50 \times 0.50 \mathrm{~m}$ and arranged for natural drying until the equilibrium moisture content was achieved with the ambient temperature (10 to I2\%). Next, the veneers were oven dried at $80^{\circ} \mathrm{C}$ until 5 to $6 \%$ moisture content was achieved.

Prior to the laminar inclusion, the dried veneers were classified in the decreasing order of quality into classes (A, B, C, D), based on the Brazilian Standard ISO 2426-2 - Wood Plywood: Classification, the Brazilian Association of Technical Standards (ABNT, 2006). The Eucalyptus veneers were classified as classes $A$ and $B$ and the Pinus veneers as $B$ and $C$ classes.

\section{Laminar inclusion}

Commercial sugarcane bagasse particleboards were subjected to the laminar inclusion process. This involved using Eucalyptus and Pinus veneers at two different pressures, as shown in Table I. For each treatment, three replicates were evaluated.

For the laminar inclusion the urea-formaldehyde adhesive was used at the weight of $180 \mathrm{~g} \cdot \mathrm{m}^{-2}$, following a simple glue line. The adhesive was spread on the veneers which were glued to the panels on both sides and subsequently pressed at $150^{\circ} \mathrm{C}$ temperature for 5 minutes. Two pressing pressures of 10 to $15 \mathrm{kgf} \cdot \mathrm{cm}^{-2}$

TABLE I Description of the inclusion laminar treatments.

\begin{tabular}{ccc}
\hline Treatment & $\begin{array}{c}\text { Pressure } \\
\left(\mathrm{kgf} \cdot \mathrm{cm}^{-2}\right)\end{array}$ & Wood \\
\hline Control & - & - \\
Pinus 10 & 10 & Pinus \\
Pinus 15 & 15 & \\
Eucalyptus 10 & 10 & Eucalyptus \\
Eucalyptus 15 & 15 & \\
\hline
\end{tabular}


were tested, according to the predetermined treatment, as shown in Table I.

\section{Physical and mechanical properties}

The tests for the physical characterization included the water absorption after two and twenty-four hours of immersion (WA2h and WA24h) and thickness swelling after two and twenty-four hours of immersion (TS2 $\mathrm{h}$ and TS24h), according to the guidelines of ASTM D-1037 (American Society for Testing and Materials ASTM, 2006). The moisture content and density were assessed according to the procedures described by NBR I48I0-3 (ABNT, 2006).

For the mechanical characterization of the panels, static flexural (modulus of elasticity and modulus of rupture) and Janka hardness test was done according to DIN 52362 (DIN, 1982).

\section{Evaluation of the results}

The experiment was conducted in a completely randomized design with three replications, in which the treatments were arranged in a factorial $2 \times 2+1$ (two wood species - Eucalyptus and Pinus, two pressure levels - 10 and I $5 \mathrm{kgf} \cdot \mathrm{cm}^{-2}$; and a control). Due to differentiation for the treatments in different types of test was used the Scott-Knott medium test, at $5 \%$ significance.

\section{RESULTS AND DISCUSSION}

\section{Bulk density and moisture}

Table 2 shows the mean values of the bulk density and moisture of the panels for the various treatments examined.

No statistical difference was observed in the bulk density of the different treatments evaluated. All the treatments were classified as medium density particleboard, which included panels having a density between 0.59 and $0.80 \mathrm{~g} \cdot \mathrm{cm}^{-3}$ (NBR I48I0-2, 2006).

For moisture of the panels no significant effect was observed for the treatments applied. All the treatments

TABLE 2 Mean values of the bulk density and moisture of the panels.

\begin{tabular}{ccc}
\hline Treatments & $\begin{array}{c}\text { Bulk Density } \\
\left(\mathrm{kg} \cdot \mathrm{m}^{-3}\right)\end{array}$ & $\begin{array}{c}\text { Moisture } \\
(\%)\end{array}$ \\
\hline Pinus I0 & $660^{(0.02)} \mathrm{a}$ & $10.0^{(2.2)} \mathrm{a}$ \\
Pinus I5 & $680^{(0.02)} \mathrm{a}$ & $11.3^{(1.7)} \mathrm{a}$ \\
Eucalyptus I0 & $650^{(0.03)} \mathrm{a}$ & $7.7^{(3.7)} \mathrm{a}$ \\
Eucalyptus I5 & $640^{(0.02)} \mathrm{a}$ & $10.9^{(1.5)} \mathrm{a}$ \\
Control & $610^{(0.04)} \mathrm{a}$ & $9.3^{(2.5)} \mathrm{a}$ \\
\hline
\end{tabular}

Means followed by the same letter show no statistical difference by the ScottKnott test at $5 \%$ significance level. The standard deviation values are given within the parentheses. were in accordance with the marketing standard EN 312 (European Committee for Standardization, 1993), which determined the suitability of the values of the moisture in the panels ranging from 5 to $13 \%$.

\section{Physical properties}

\section{Water absorption}

Table 3 shows the mean values of water absorption after two (WA2h) and after twenty-four hours (WA24h) of immersion for each of the treatments assessed. All variations in the average values obtained for the laminar panels, including the panels relative to the control, are also listed.

TABLE 3 Mean values of water absorption after two and

\begin{tabular}{|c|c|c|c|c|}
\hline \multirow{2}{*}{ Treatment } & WA2h & $\Delta$ & WA24h & $\Delta$ \\
\hline & \multicolumn{4}{|c|}{$\%$} \\
\hline Pinus 10 & $10.3^{(1.3)^{*}}$ & -46.9 & $26.8^{(3.4)^{*}}$ & -55.2 \\
\hline Pinus I5 & $10.8^{(1.6)^{*}}$ & -44.3 & $29.5^{(4.2)^{*}}$ & -50.7 \\
\hline Eucalyptus 10 & $9.0^{(1.5)^{\circ}}$ & -53.6 & $29.5^{(2.3)^{*}}$ & -50.7 \\
\hline Eucalyptus I5 & $8.3^{(1.3)^{\circ}}$ & -57.2 & $26 . I^{(4.0) *}$ & -56.4 \\
\hline Control & $19.4^{(7.8)}$ & & $59.8^{(13.4)}$ & \\
\hline
\end{tabular}

*Statistical difference observed by Dunnett's test $(\alpha=0.05)$ from the control treatment. The standard deviation values are given within the parentheses.

All the treatments with laminar inclusion showed statistically different lower WA2h and WA24h values, in comparison to the control panel. The reductions were approximately 44.3 to $57.2 \%$ for $\mathrm{AA} 2 \mathrm{~h}$ and 50.7 to $56.4 \%$ for WA24h.

According to Mendes et al. (2010) the lowest value of water absorption obtained by the laminar inclusion of the panels was a result of the barrier caused by the adhesive film used for the bonding of the veneers and the veneers themselves, which impeded the water penetration through the surfaces. Another factor was the greater compactness of the mattress particles produced by the pressure used for bonding the veneers and the water penetration barrier generated by the veneer added to the panel, which has a smaller surface area for water absorption than the panel particles.

Iwakiri et al. (2003) evaluated the influence of the orientation of the strand particles and laminar inclusion using the wood of the loblolly Pinus on the physic-mechanical properties of the OSB panels with the phenol formaldehyde adhesive. The average values for WA2h and WA24h with the laminar inclusion and strand particles randomly arranged, were 41.8 and 58.8\%, respectively, showing a reduction of 18.8 and $9.5 \%$, respectively, when compared with the laminar panels without inclusion. 
Mesquita et al. (20I2) evaluated the influence of laminar inclusion on the physical properties of the MDP sugarcane bagasse using veneers from the species Pinus oocarpa glued with phenol formaldehyde adhesive. For the WA2h property the average value obtained was $13.4 \%$, whereas for the WA24h the average value was 30.6\%.

Colli et al. (2007) evaluated the inclusion of Paricá veneers in particleboards produced with Eucalyptus and Paricá wood using urea-formaldehyde adhesive. Mean values of I22.I and I46.6\% were obtained for the WA2h and WA24h, respectively.

Also related to the data obtained for the properties of WA2h and WA24h (Table 4) neither interaction nor statistical difference was observed between the two species (Pinus and eucalyptus) at the two pressures used ( 10 and $\left.15 \mathrm{kgf} \cdot \mathrm{cm}^{-2}\right)$.

TABLE 4 Mean values of water absorption after two and twenty-four hours depending on the wood species and pressure.

\begin{tabular}{ccccc}
\hline & \multicolumn{2}{c}{ WA2h (\%) } & \multicolumn{2}{c}{ WA24h (\%) } \\
\cline { 2 - 5 } Wood Type & \multicolumn{4}{c}{ Pressure $\left(\mathrm{kgf} \cdot \mathrm{cm}^{-2}\right)$} \\
\cline { 2 - 5 } & 10 & 15 & 10 & 15 \\
\hline Pinus & $10.3^{(1.3)} \mathrm{aA}$ & $10.8^{(2.6)} \mathrm{aA}$ & $26.8^{(3.4)} \mathrm{aA}$ & $29.5^{(4.2)} \mathrm{aA}$ \\
Eucalyptus & $9.0^{(1.5)} \mathrm{aA}$ & $8.3^{(1.3)} \mathrm{aA}$ & $29.5^{(2.3)} \mathrm{aA}$ & $26 . \mathrm{I}^{(4.0)} \mathrm{aA}$ \\
\hline
\end{tabular}

Means followed by the same letter show no statistical difference by the ScottKnott test at $5 \%$ significance level. The lower case letters refer to the values of the columns while the capitals indicate the values of the lines. The standard deviation values are given within the parentheses.

\section{Thickness swelling}

Table 5 shows the average values of the thickness swelling after two hours (TS2h) and after twenty-four hours (TS24h) of immersion for each of the treatments evaluated. As well as the variation of the average values obtained for the panels with laminar inclusion in relation the control panels.

All the treatments with laminar inclusion were showed lower average values of TS2h, differing

TABLE 5 Mean values of swelling in thickness after two and twenty-four hours of immersion in water.

\begin{tabular}{|c|c|c|c|c|}
\hline \multirow{2}{*}{ Treatments } & TS2h & $\Delta$ & TS24h & $\Delta$ \\
\hline & \multicolumn{4}{|c|}{$\%$} \\
\hline Pinus 10 & $2.7^{(0.6)^{\circ}}$ & -53.4 & $9.7^{(1.5)} \mathrm{ns}$ & -21.8 \\
\hline Pinus 15 & $3.5^{(0.9)^{*}}$ & -39.7 & $12.8^{(1.6)} \mathrm{ns}$ & 3.2 \\
\hline Eucalyptus 10 & $2.9^{(0.9) *}$ & -50.0 & $\mathrm{I} \mid .55^{(1.7)} \mathrm{ns}$ & -7.3 \\
\hline Eucalyptus I5 & $3.0^{(0.7)^{\circ}}$ & -48.3 & $10.9^{(2.7)} \mathrm{ns}$ & -12.1 \\
\hline Control & $5.8^{(1.4)}$ & & $12.4^{(1.2)}$ & \\
\hline
\end{tabular}

*Statistical difference by Dunnett's test $(\alpha=0.05)$ from the control treatment; ns Shows no Statistical difference by Dunnett's test $(\alpha=0.0 \mathrm{I})$ in the control treatment. The standard deviation values are given within the parentheses. statistically from the control panels. The reductions were approximately 39.7 to $53.4 \%$. These smaller average values indicated the presence of the barrier provided by the adhesive film used for bonding the veneers, which hindered the penetration of the water by the face, as well as the greater compactness of the particles of the mattress enhanced by the veneers pressing on them (MENDES et al., 2012a).

However, no effect due to laminar inclusion was observed for the TS24h, which could be associated with some factors, such as: i) The increased release of stress in these panels with laminar inclusion over time, when in contact with water, causing a certain increase of WA24h and TS24h in relation to WA2h and TS2h (Tables 3 and $5)$, with less influence; and ii) The dimensional movement of the veneers in the radial direction and both surfaces of the panels, according to Kollmann \& Côté (1968), radial swelling is between 2.5 and $5.2 \%$ for coniferous woods.

Mesquita et al. (2012) evaluated the influence by laminar inclusion on the physical properties of the MDP sugarcane bagasse using veneers from the species Pinus oocarpa glued with phenol formaldehyde adhesive. For the TS2h property the average value obtained was $2.9 \%$, whereas for the TS24h the average value was $9.1 \%$.

Iwakiri et al. (2003) evaluated the influence of the strand particles orientation and laminar inclusion using the Pinus taeda wood on the physico-mechanical properties of the panels glued with the phenol formaldehyde adhesive. The average values obtained for the TS2 $h$ and TS24h, for the panels with laminar inclusion and the random "strand" arrangement of particles was 21.2 and $26.1 \%$, respectively. This implied a reduction of around 23.0 and $25.6 \%$, respectively, when compared with the panels without laminar inclusion.

Iwakiri et al. (2009) evaluated the effect of the laminar inclusion in OSB with Pinus taeda wood, and obtained reduced values of 16.7 and $17.1 \%$ for the property of thickness swelling after two and twenty-four hours of immersion, respectively.

When compared with the research available in the literature, the inclusion laminar in sugarcane bagasse panels had a more significant effect. The standard of Brazilian trade (NBR 14810, 2013) determines the maximum value for the TS24h as $18 \%$, the European Standard (EN 3I2, 2003) has a maximum value of $14 \%$ and the American Standard (ANSI A208.I, 2009) has a value to a maximum of $8 \%$. In this sense, all the panels subject to the treatments met the Brazilian and European standards, although they required some tweaking in the process to meet the American criteria, keeping the export of this product in mind, for the future. 
Also, regarding the data obtained for the TS2 $h$ and TS24h properties (Table 6), neither interaction nor statistical difference was noted between the two species (Pinus and Eucalyptus) and the two used pressures ( 10 and $\left.15 \mathrm{kgf} \cdot \mathrm{cm}^{-2}\right)$.

TABLE 6 Mean values of swelling in thickness after two and twenty-four hours, also based on the species and pressure.

\begin{tabular}{ccccc}
\hline \multirow{2}{*}{ Wood Type } & \multicolumn{2}{c}{ TS2h (\%) } & \multicolumn{3}{c}{ TS24h (\%) } \\
\cline { 2 - 5 } & \multicolumn{4}{c}{ Pressure $\left(\mathrm{kgf} \cdot \mathrm{cm}^{-2)}\right.$} \\
\cline { 2 - 5 } & 10 & 15 & 10 & 15 \\
\hline Pinus & $2.7^{(0.6)} \mathrm{aA}$ & $3.5^{(0.9)} \mathrm{aA}$ & $9.7^{(1.5)} \mathrm{aA}$ & $12.8^{(1.6)} \mathrm{aA}$ \\
Eucalyptus & $2.9^{(0.9)} \mathrm{aA}$ & $3.0^{(0.7)} \mathrm{aA}$ & $11.5^{(1.7)} \mathrm{aA}$ & $10.9^{(2.7)} \mathrm{aA}$ \\
\hline
\end{tabular}

Means followed by the same letter show no statistical difference by the ScottKnott test at $5 \%$ significance level. The lower case letters refer to the values of the columns while the capitals indicate the values of the lines. The standard deviation values are given within the parentheses.

\section{Mechanical properties}

\section{Modulus of rupture and modulus of elasticity to bending}

Tables 7 and 8 show the mean values of the modulus of elasticity perpendicular $(\mathrm{MOE} \perp)$, modulus of elasticity parallel (MOE //), modulus of rupture perpendicular $(M O R \perp)$ and modulus of rupture parallel (MOR //) for each of the treatments evaluated. The variations in the average values obtained for the laminar panels including panels relative to the control are also shown.

TABLE 7 Mean values of modulus of rupture parallel and perpendicular.

\begin{tabular}{ccccc}
\hline \multirow{2}{*}{ Treatments } & $\mathrm{MOR} / /$ & $\Delta$ & $\mathrm{MOR} \perp$ & $\Delta$ \\
\cline { 2 - 5 } & $\mathrm{MPa}$ & $(\%)$ & $\mathrm{MPa}$ & $(\%)$ \\
\hline Pinus I0 & $32.2^{(4.5)^{*}}$ & 98.8 & $12 . \mathrm{I}^{(0.7)^{*}}$ & -25.3 \\
Pinus I5 & $24.5^{(6.4)} \mathrm{ns}$ & 51.2 & $11.4^{(3.0)^{*}}$ & -29.6 \\
Eucalyptus 10 & $33.1^{(6.4)^{*}}$ & $104.3^{*}$ & $11.3^{(1.1)^{*}}$ & -30.2 \\
Eucalyptus 15 & $38.3^{(1.1)^{*}}$ & 136.4 & $11.5^{(1.4)^{*}}$ & -29.0 \\
Control & $16.2^{(4.4)}$ & & $16.2^{(4.4)}$ & \\
\hline
\end{tabular}

*Statistical difference by Dunnett's test $(\alpha=0.05)$ from the control treatment; ns Shows no Statistical difference by Dunnett's test $(\alpha=0.01)$ in the control treatment. The standard deviation values are given within the parentheses.

To assess the MOR parallel, by comparison of the Dunnett test, only the treatment with pinus veneers and pressure of $15 \mathrm{~kg} \cdot \mathrm{cm}^{-2}$ did not differ statistically from the control panel. The reduction in the average value obtained from this treatment may be related to the high pressure used, which caused the disruption of some anatomical constituents of the pinus veneer. The other treatments differed significantly from the control panel, an increase in the parallel mor value from 98.8 to $136.4 \%$.
For the average values for MOR perpendicular, all the treatments differed significantly from the control panel (without laminar inclusion). The reduction in the average values obtained from the laminar inclusion was in the range of -25.3 to $-30.2 \%$. This fact is associated with disruption of the veneers by traction tension in the samples of bending, there is seen in the direction being exposed to load. Instead of having a number of randomly dispersed particles as in the case of agglomeration, the agglomerated inclusion has veneers in the required direction, perpendicular to the wood fibers, being one of the lowest resistances of the wood.

TABLE 8 Mean values of modulus of rupture parallel and perpendicular.

\begin{tabular}{|c|c|c|c|c|}
\hline \multirow{2}{*}{ Treatments } & MOE // & $\Delta$ & $\mathrm{MOE} \perp$ & $\Delta$ \\
\hline & $\mathrm{MPa}$ & (\%) & $\mathrm{MPa}$ & (\%) \\
\hline Pinus 10 & $3932.7^{(366.6) *}$ & 117.5 & $1226.5^{(110.4)} \mathrm{ns}$ & -32.2 \\
\hline Pinus 15 & $3377.6^{(527.6) *}$ & 86.8 & I I $07.4^{(229.9) *}$ & -38.7 \\
\hline Eucalyptus 10 & $4066.5^{(339.7)^{*}}$ & 124.9 & $1|4| .3^{(196.5)^{*}}$ & -36.9 \\
\hline Eucalyptus I5 & $5618.3^{(3336.2)^{\circ}}$ & 210.8 & I $204.8^{(97.8)} \mathrm{ns}$ & -33.4 \\
\hline Control & $1807.8^{(401.2)}$ & & $1807.8^{(401.2)}$ & \\
\hline
\end{tabular}

*Statistical difference by Dunnett's test $(\alpha=0.05)$ from the control treatment; ns Shows no Statistical difference by Dunnett's test $(\alpha=0.0 \mathrm{I})$ in the control treatment. The standard deviation values are given within the parentheses.

Looking at the average values for the MOE parallel, all the treatments showed significant differences from the control panel, with good improvement for this property, recording an increase in the average values from 86.8 to $210.8 \%$.

The MOE perpendicular property, was compared by Dunnett test, only the treatments with Pinus venners subjected to a pressure of $10 \mathrm{kgf} \cdot \mathrm{cm}^{-2}$ and Eucalyptus veneers to a pressure of $15 \mathrm{kgf} \cdot \mathrm{cm}^{-2}$, showed no statistical difference from the control panel. The other treatments, Pinus veneers with pressure $15 \mathrm{~kg} \cdot \mathrm{cm}^{-2}$ and Eucalyptus with pressure of $10 \mathrm{kgf} \cdot \mathrm{cm}^{-2}$, differed significantly from the control panel, with a reduction in the average values obtained from the laminar inclusion in the range of -38.7 and $-36.9 \%$, respectively. This drop in the values is explained using the same reasons discussed above for the MOR, being them the direction of the fibers and the direction of the load applied. According to Iwakiri et al. (1999), the decrease in the MOE and MOR values in the perpendicular direction and the panels with laminar inclusion can be attributed to the lesser bending strength of wood in the direction perpendicular to the fibers.

Iwakiri et al. (1999) while evaluating the effect of the laminar inclusion in the particleboard using Pinus elliottii veneers glued with urea-formaldehyde adhesive, obtained the average values of 2749.1 and $16.5 \mathrm{MPa}$, 
increases 79.5 and $135.1 \%$, respectively, for the MOE and MOR perpendicular properties, compared with the panels without the inclusion veneers. For the MOE and MOR parallel, the average values were 8478.2 and 48.4 $\mathrm{MPa}$, with a drop of 42.3 and $20.6 \%$, respectively.

Colli et al. (2007) evaluated the laminar inclusion with Paricá veneers in particleboard with Eucalyptus and Paricá wood and using urea-formaldehyde adhesive. They found mean values between I0.7 and 16.7 MPa for the MOR; for MOE the average values were in the range of 2364.4 at $2961.6 \mathrm{MPa}$.

Mendes et al. (2012a) evaluated the influence of the laminar inclusion and adhesive type (ureaformaldehyde and phenol-formaldehyde) on the physical and mechanical properties of the OSB made with Pinus oocarpa, recorded average values for the MOE and MOR parallel at 7406.6 and 4I.0 $\mathrm{MPa}$, respectively. These values indicated an increase of 12.0 and $16.8 \%$, respectively, compared with the panels without laminar inclusion. For the MOE and MOR perpendicular, the average values were 4466.7 and $24.7 \mathrm{MPa}$, respectively, an increase of $2.2 \%$ for the MOE and $5.7 \%$ for the MOR.

The Brazilian standard of trade (NBR 14810, 20I3) prescribes a minimum value of II.0 MPa for the MOR and $1600 \mathrm{MPa}$ for the MOE; the European standard (EN3 I 2, 2003) determines a minimum value of I3.0 MPa for the MOR and $1600 \mathrm{MPa}$ for the MOE; and American Standard (ANSI A 208.I, 2009) specifies a minimum of I I.0 MPa for the MOR and I725 MPa for the MOE.

The panels with laminar inclusion have been noted to be restricted from usage in situations where they would be exposed to perpendicular loads, as they do not meet the marketing standards for MOE and the EN3 I 2 Standard (2013) in the case of the MOR. The panels with or without laminar inclusion meet all the criteria of the marketing standards when placed with the loads in parallel. As the panels with laminar inclusion showed values higher than those required by the standards, it is possible to apply them to new types of uses, including those of structural applications, such as inner walls.

No interaction was observed between the species and the two pressures employed, with respect to the flexural properties of the panels for MOR and MOE. Tables 9 and $\mathrm{O}$ list the average values of $\mathrm{MOE} / /, \mathrm{MOE} \perp$, $\mathrm{MOR} / /$ and $M O R \perp$ based on the species and pressure.

On assessment of the MOR and MOE parallel, no statistical difference was observed between treatments when evaluating the pressure of $10 \mathrm{kgf} \cdot \mathrm{cm}^{-2}$ within the species (Pinus and Eucalyptus) as well as when assessing each species within each pressure. However, for the pressure of $15 \mathrm{kgf} \cdot \mathrm{cm}^{-2}$ within the two species (Pinus and
Eucalyptus), a statistical difference was noted, with the Eucalyptus species showing the higher average value. This can be associated with the greater density of Eucalyptus $\left(0.56 \mathrm{~g} \cdot \mathrm{cm}^{-3}\right)$ in relation to Pinus wood $\left(0.50 \mathrm{~g} \cdot \mathrm{cm}^{-3}\right)$. There was a breaking up of some anatomical elements of the Pinus wood when the pressure of $15 \mathrm{kgf} \cdot \mathrm{cm}^{-2}$ was applied to bond the veneers to the panels.

TABLE 9 Mean values of modulus of rupture parallel and perpendicular according to species and pressure.

\begin{tabular}{ccccc}
\hline & \multicolumn{2}{c}{$\mathrm{MOR} / /(\mathrm{MPa})$} & \multicolumn{3}{c}{$\mathrm{MOR} \perp(\mathrm{MPa})$} \\
\cline { 2 - 5 } Wood Type & \multicolumn{4}{c}{ Pressure $\left(\mathrm{kgf} \cdot \mathrm{cm}^{-2}\right)$} \\
\cline { 2 - 5 } & 10 & 15 & 10 & 15 \\
\hline Pinus & $32.2^{(4.5)} \mathrm{aA}$ & $24.5^{(6.4)} \mathrm{bA}$ & $12.1^{(0.7)} \mathrm{aA}$ & $11.4^{(3.0)} \mathrm{aA}$ \\
Eucalyptus & $33.1^{(6.4)} \mathrm{aA}$ & $38.3^{(1.1)} \mathrm{aA}$ & $11.3^{(1.1)} \mathrm{aA}$ & $11.5^{(1.4)} \mathrm{aA}$ \\
\hline
\end{tabular}

Means followed by the same letter show no statistical difference by the ScottKnott test at $5 \%$ significance level. The lower case letters refer to the values of the columns while the capitals indicate the values of the lines.

The standard deviation values are given within the parentheses.

TABLE I0 Mean values of modulus of rupture parallel and perpendicular according to species and pressure.

\begin{tabular}{ccccc}
\hline \multirow{2}{*}{ Wood } & \multicolumn{3}{c}{$\mathrm{MOE} / /(\mathrm{MPa})$} & \multicolumn{2}{c}{$\mathrm{MOE} \perp(\mathrm{MPa})$} \\
\cline { 2 - 5 } Type & \multicolumn{4}{c}{ Pressure $\left(\mathrm{kgf} \cdot \mathrm{cm}^{-2}\right)$} \\
\cline { 2 - 5 } & 10 & 15 & 10 & 15 \\
\hline
\end{tabular}

Pinus $3932.7^{(366.6)}$ aA $3377.6^{(527.6)}$ bA $1226.5^{(110.4)}$ aA $1107.4^{(229.9)}$ aA Eucalyptus $4066.5^{(339.7)}$ aA $5618.3^{(3336.2)}$ aA I I $41.3^{(196.5)}$ aA $1204.8^{(97.8)}$ aA Means followed by the same letter show no statistical difference by the ScottKnott test at $5 \%$ significance level. The lower case letters refer to the values of the columns while the capitals indicate the values of the lines. The standard deviation values are given within the parentheses.

For the MOR and MOE perpendicular properties, no statistical difference was observed between the treatments, either when the pressures ( 10 and I $5 \mathrm{~kg} \cdot \mathrm{cm}^{-2}$ ) were measured within the species (Pinus and Eucalyptus) or when assessing each species within each pressure.

\section{Janka Hardness}

Table I I lists the mean values of Janka hardness for all the treatments and the variation in the average values of the panels with laminar inclusion in relation to the control panel.

TABLE I I Mean values of modulus of rupture parallel and perpendicular according to species and pressure.

\begin{tabular}{ccc}
\hline Treatments & Janka Hardness $(\mathrm{MPa})$ & $\Delta(\%)$ \\
\hline Pinus I0 & $29.1^{(4,1)^{*}}$ & 32.3 \\
Pinus I5 & $31.9^{(4,0) *}$ & 45.0 \\
Eucalyptus I0 & $34.2^{(3,4)^{*}}$ & 55.5 \\
Eucalyptus I5 & $34.9^{(4,2)^{*}}$ & 58.6 \\
Control & $22.0^{(3,1)}$ & \\
\hline
\end{tabular}

*Statistical difference by Dunnett's test $(\alpha=0.05)$ from the control treatment; The standard deviation values are given within the parentheses. 
On comparison of the Dunnett test for the property of Janka hardness, all the treatments were statistically different from the control panel. A significant increase in the mean values was observed for this property with laminar inclusion, with elevations ranging from 32.3 to $58.6 \%$.

Both for the MOE and MOR in parallel, as well as Janka hardness, the highest average values were obtained for the treatments utilizing the Eucalyptus veneers with both pressures ( 10 and $15 \mathrm{kgf} \cdot \mathrm{cm}^{-2}$ ). This can be explained as being due to the higher density of the Eucalyptus wood against the Pinus wood.

Colli et al. (2007) evaluated the laminar inclusion with Paricá veneers in particleboard with Eucalyptus and Paricá wood glued with urea-formaldehyde adhesive. They obtained mean values between II.3 and I5.7 MPa for Janka hardness.

Oliveira et al. (2016) in their evaluation of the panels with Pinus, Eucalyptus and Sugarcane bagasse, recorded average values of 33.9 $\mathrm{MPa}$ for Janka hardness for the sugarcane bagasse panels.

Only those treatments with laminar inclusion managed to meet the minimum values specified by the marketing standard ANSI A208-I (ANSI, 2009), which established the minimum Janka hardness value of 22.7 MPa for particleboard.

No interaction was observed between the two species (Pinus and Eucalyptus) and the two pressures used ( 10 and $15 \mathrm{kgf} \cdot \mathrm{cm}^{-2}$ ) for the Janka hardness property (Table 12). No statistical difference was observed between the treatments when the pressures ( 10 and 15 $\mathrm{kgf} \cdot \mathrm{cm}^{-2}$ ) were evaluated within each species (Pinus and Eucalyptus) as well as when evaluating each species with each pressure.

TABLE 12 Mean values of Janka hardness (MPa) depending on the species and pressure used to laminar inclusion.

\begin{tabular}{ccc}
\hline \multirow{2}{*}{ Wood Type } & \multicolumn{2}{c}{ Pressure $\left(\mathrm{kgf} \cdot \mathrm{cm}^{-2}\right)$} \\
\cline { 2 - 3 } & 10 & 15 \\
\hline Pinus & $29.1^{(4.1) \mathrm{aA}}$ & $31.9^{(4.0)} \mathrm{aA}$ \\
Eucalyptus & $34.2^{(3.4) \mathrm{aA}}$ & $34.9^{(4.2)} \mathrm{aA}$ \\
\hline
\end{tabular}

*Statistical difference by Dunnett's test $(\alpha=0.05)$ from the control treatment; The standard deviation values are given within the parentheses.

\section{CONCLUSIONS}

There was no statistical difference noted between the treatments with laminar inclusion and control panel for the properties of bulk density and moisture content.

All the treatments with laminar inclusion showed significant reductions in the values of $A A 2 h, A A 24 h$ and IE2h. There was a significant increase in the MOE and MOR properties in parallel and in Janka hardness, whereas the MOE and MOR properties in perpendicular decreased significantly.

No interaction was observed among the factors of type of wood species and pressure used in the laminar inclusion.

The pinus and eucalyptus veneers inclusion obtained similar results when added to the panel with a $10 \mathrm{~kg} \cdot \mathrm{cm}^{-2}$ pressure. The use of $15 \mathrm{kgf} \cdot \mathrm{cm}^{-2}$ pressure is not indicated for the Pinus veneer inclusion in sugar cane bagasse panels.

There was no effect of the pressure level when evaluating the eucalyptus veneer inclusion on the properties of the sugarcane bagasse panels.

\section{REFERENCES}

AMERICAN NATIONAL STANDARD. ANSI A208.I: Particleboard Standard. National particleboard assoc., Leesburg, 2009.

AMERICAN SOCIETY FOR TESTING AND MATERIAL. ASTM D 1037 - Standard methods of evaluating the properties of wood-base fiber and particle panel materials. Philadelphia, 2006.

ANDRADE, P.I.; ARAÚJO, S.O.; NEIVA, D.M.; VITAL, B.R.; CARNEIRO, A.C.O.; GOMINHO, J.; PEREIRA, H. Strength properties and dimensional stability of particleboards with different proportions of thermally treated recycled Pinus particles. Holzforschung. v. 70, n. 5, 467-474, 2016.

ASSOCIAÇÃO BRASILEIRA DE NORMAS TÉCNICAS. NBR I48 I 0-2: Chapas de madeira aglomerada - requisitos. Rio de Janeiro, 2006. 4 p. Parte 2.

ASSOCIAÇÃO BRASILEIRA DE NORMAS TÉCNICAS. NBR 148 I0-3: Chapas de madeira aglomerada - métodos de ensaio. Rio de Janeiro, 2006. 5 I p. Parte 3.

ASSOCIAÇÃO BRASILEIRA DE NORMAS TÉCNICAS. NBR ISO 2426-2: Chapas de madeira compensada Classificação. Rio de Janeiro, 2006. 3p. Parte 2.

DE BARROS FILHO, R. M., MENDES, L. M., NOVACK, K. M., APRELINI, L. O. E BOTARO, V. R. Hybrid chipboard panels based on sugarcane bagasse, urea formaldehyde and melamine formaldehyde resin. Industrial Crops and Products, v. 33, n.2, p. 369-373, 2011.

COLLI, A.; NAUMANN, R.; VITAL, B.R.; VIDAURRE, G.; FREDERICO, P. G.U.; ZANETI, L. Chapas de partículas aglomeradas com inclusão laminar. Revista da Madeira, n 106, 2007.

DEUTSCHES INSTITUT FÜR NORMUNG - DIN. Normen für Holzfaserplaten Spanplatten Sperrholz. DIN 52362: Testing of wood chipboards bending test, determination of bending strength. Berlin; 1982. p. 39-40. 
EUROPEAN COMMITTEE FOR STANDARDIZATION. EN 312: particleboard: specifications. Bruxelas, 1993.

Food and Agriculture Organization of the United Nations -FAOSTAT. Rome. Access in: 07/02/2013.

IWAKIRI, S; COSTA, A.F.; KLITZKE, R.J.; NIELSEN, I.R.; ALBERTI, R.A.R; NIEFE, I. Produção de chapas de madeira aglomerada de Pinus elliottii engelm. com inclusão laminar. Cerne, v.5, n.2, p. 086-094, 1999.

IWAKIRI, S.; MONTEFUSCO, A.R.G.; ZABLONSKY, K.M.; SIQUEIRA, K.P.; SALDANHA, L.K.; SOUZA, M.A.M.. Produção de chapas de partículas strand com inclusão laminar COM-PLAY. Floresta e Ambiente, Seropédica, v. I0, n. 2, p. 30-35, 2003.

IWAKIRI, S. Painéis de madeira reconstituída. Curitiba: FUPEF. 2005, 274p.

IWAKIRI, S.; SALDANHA, L.K.; ALBUQUERQUE, C.E.C.; MENDES, L. M. Influência da espessura de partículas e reforço laminar nas propriedades dos painéis de partículas orientadas OSB de Pinus taeda L. Cerne, Lavras, v. I5, n. I, p. II6-I22, 2009.

KNOW, J. H.; AYRILMIS, N.; HAN, T. H. Enhancement of flexural properties and dimensional stability of rice husk particleboard using wood strands in face layers. Composites Part B: Engineering. v. 44, n. I, 728-732, 2013.

KOLLMANN, F.R.; COTÉ, W.A. Principles of Wood science and technology. Berlin, Springer-Verlag. 1968. 592p.

MENDES, RF, GUIMARÃES JÚNIOR, JB, SANTOS, RC, BUFALINO, L. The adhesive effect on the properties of particleboards made from sugar cane generated in the distiller. Revista de Ciências Agrárias, v.32, n.2, p. 209218, 2009.

MENDES, R.F.; MENDES, L.M.; BUFALINO, L; SILVA, AFA. Influência do tipo de adesivo e da inclusão laminar nas propriedades físicas de painéis OSB. In: Anais do XII Encontro brasileiro em madeiras e em estruturas de madeira - EBRAMEM; UFLA, Lavras, 2010.

MENDES, R.F.; MENDES, L.M.; CARVALHO, A.G.; SILVA, A.F.A.; GUIMARÃES JÚNIOR, J.B. Efeito da inclusão laminar e do tipo de adesivo sobre as propriedades de painéis OSB de Pinus oocarpa. Ciência da Madeira, Pelotas, v. 03, n. 02 , p. II6-I27, 20I2a.
MENDES, R.F; MENDES, L.M.; GUIMARÃES JÚNIOR, J.B.; MENDONÇA, L.L. Qualidade de painéis aglomerados produzidos na china utilizando bagaço de cana. In: Anais do XI Encontro Brasileiro em Madeiras e Estruturas de Madeira - EBRAMEM; Londrina, PR. Londrina: Editora UEL, 2008.

MENDES, R.F.; MENDES, L.M; TONOLI, G.H.D.; BUFALINO, L; MORI, F.A.; GUIMARÃES JÚNIOR, J.B. Lignocellulosic composites made from agricultural and forestry wastes in Brazil. Key Engineering Materials, 5I7, p. 556-563, 20 I 2 b.

MESQUITA, R.G.A.; MENDES, R.F.; CAIXETA, L.A.; MENDES, L.M.; TONOLI, G.H.D. Propriedades físicas de painéis MDP com inclusão laminar. In: Anais do XIII Encontro brasileiro em madeiras e em estruturas de madeira. UFES, Vitória, 2012

OLIVEIRA, S.L.; MENDES, R.F.; MENDES, L.M.; FREIRE, T.P. Particleboard panels made from sugarcane bagasse: Characterization for use in the furniture industry. Materials Research, v. 19, n.4, p. 914-922, 2016.

ROWELL, R.M; HAN, J.S; ROWELL, J.S. Characterization and factors affecting fiber properties. In: FROLLINI, E.; LEÃO, A.L.; MATTOSO, L.H.C. Natural polymers and agrofibers based composites. Section II: Agrofibers composites, 2000. São Carlos: Embrapa Instrumentação Agropecuária; p. II5-134.

SILVA, V.L.M.M.; GOMES, W.C.O.; ALSINA, L.S. Utilização do bagaço de cana de açúcar como biomassa adsorvente na adsorção de poluentes orgânicos. Revista Eletrônica de Materiais e Processos, 2:27-32, 2007.

United States Department of Agriculture - USDA. Relatório safra 20I5/20I6. Available in: https://www.usda.gov/wps/ portal/usda/usdahome Acess in: 23/0I/20I7.

VITAL, B.R.;ANDRADE, PI.L.; CARNEIRO, A.C.O.; CABRAL, C.P.T.; CARVALHO, A.M.M. Estabilidade dimensional e resistência à tração perpendicular de painéis fabricados com partículas termorretificadas oriundas de embalagens de Pinus sp. Revista Árvore, Viçosa-MG, v.38, n.5, p.95I-959, 2014.

WIDYORINI, R.; XU, J.; UMEMURA, K.; KAWAI, S. Manufacture and properties of binderless particleboard from bagasse I: Effects of raw material type, storage methods, and manufacturing process. Journal of Wood Science, v.5I, n.6, p.648-654, 2005.

XU, X.; YAO, F.; WU, Q.; ZHOU, D. The influence of waxsizing on dimension stability and mechanical properties of bagasse particleboard. Industrial Crops and Products, v.29, n. I, p.80-85, 2009. 